\title{
Militancy and Sustainable Development in the Niger Delta: Excerpts from the Fourth Republic
}

\author{
Voke Charles Mgbonyenbi \& Frank C.A. Emeni \\ http://dx.doi./org/10.4314/ujah.v21i4.5
}

\begin{abstract}
The resurgence of militancy in the Niger Delta region of Nigeria and Delta State in particular has reached a seemingly high level, which has contributed to the crumbling economy of Nigeria as these series of attacks on oil facilities have reduced the barrel production of crude oil per day in the region. This has posed an imminent threat with the ongoing economic meltdown in the country. The identified reasons have been the cutbacks on the amnesty arrangements, the environmental degradation and continuous deprivation of the oil rich regions from the proceeds of the oil derived from their region and demand for ownership of the region by residents which has affected sustainable development in Delta state. This work however, through the means of empirical study, pinpoints the several reasons for the resurgence of militancy in the Niger Delta region and its effect on sustainable development in Delta state and the viability of the group's bluff in crippling the Nigerian economy. The Study is anchored on the frustration Aggression theory and adopted the primary method of data collection. The study recommends some viable solutions amongst which are; giving more credence to the importance of Niger Delta region, developmental projects that are supervised by stakeholders and disinterested organizations in the region and Delta state in Particular.
\end{abstract}

Keywords: Militancy, Sustainable Development, Security 


\section{Introduction}

The Niger Delta region in Nigeria extends over about 70,000km2 and makes up about 75 of Nigerian land mass. It consists presently of nine (9) states namely, Rivers, Cross River, Akwa Ibom, Imo, Delta, Edo, Ondo, Abia and Bayelsa. The region has a population of 30 million people in 2006 which is about 23 percent of the total Nigerian population of 140 million. The people of the region rely mainly on farming and fishing as their major source of livelihood (Saro Wiwa, 1998). Niger Delta Region is the geographical heart of crude oil exploration in Nigeria from where the nation earns up to 99.7 and 90 percent of its export and annual income respectively (IMF, 2003; Azaiki, 2007).

According to Barry, the issue of security, peace and development remains at the center of focus on national and international research and discourse. As security remains a lost entity in which developing countries are always seeking out. Nigeria was granted flagged independence on October 1st 1960, but it has not really enjoyed the peace of being an independent country. There exists economic, political, and socioeconomic crisis, which have always had its way in turning into issues of national security. On National security, Mandel believed that it is the achievement of psychological and physical safety of the citizenry, which is the responsibility of the government, and also the prevention of physical threats to the survival of the existing norms, beliefs and culture of the citizenry and the country at large. Iyayi agrees with the communities in the Niger Delta region on the issue of antagonizing the government and the oil majors, because he believes that the Niger Delta crisis from its inception has always been a result of the fatal consequence of oil extraction on the environment and also the inadequacy in the appropriation of the proceeds from the huge revenue generated from oil extracted from the region. In view of this, the issue of insecurity in the Niger Delta region, especially militancy would remain a recurring 
one till a lasting and sustainable solution can be proffered to the reasons for the agitations in the region. Niger Delta region is now as it is an unsafe region in the country, as the resurgence of militancy by the allegedly tactical and formidable Niger Delta Avengers have once again promoted insecurity and uncertainty as to what the future holds as regards the economy and security of both the region and the country as a whole. It has also brought about a major fall in the oil production process in the region due to the incessant attacks on oil facilities in the region. The Niger Delta Avengers are believed to be energetic, sophisticated and calculative in their attacks compared to previous militant groups, such as; MEND, NDYDF, etc. Emmanuel Ibe Kachikwu, said that oil production has reduced by 800,000 barrels per day to 1.4 million barrels per day, due to the series of attacks on the country's oil facilities in the Niger Delta region by the Avengers. Lastly, the resurgence of militancy in the Niger Delta area do not only pose threats to the region, but Nigeria at large, considering the ongoing fall in the oil price and also the economic challenges in the country. This work however, would be investigating the challenges that brought about the resurgence of militancy in the Niger Delta and its implication on Sustainable development in Nigeria.

The Niger Delta remains an important region to Nigeria due to its massive contribution to the economy of the country through its oil resources. However, the resurgence of militancy in the region poses serious challenges to not only the region but also the national security of the country. These challenges as they appear in the Niger Delta area include; bombings of oil facilities, kidnapping, oil bunkering. Responsibilities for most of the recent attacks in Niger Delta have been claimed by a group named Niger Delta Avengers, which intends to deal consequent attacks on the region, with the futuristic motives of crippling the Nigerian economy. Militancy in the Niger Delta region is not a recent development, but it has been suppressed to the barest minimum in the past through several policy and military actions by 
the Government and supposed contribution from the oil majors, such as; establishment of the NDDC, Ministry of Niger Delta affairs, Amnesty Programme, JTF operations, etc. Despite the supposed importance accrued to the Niger Delta region and efforts in combating militancy in the region, there has been resurgence of militancy and incessant security crisis which have undermined development. Is the Niger Delta really the bedrock of the Nigerian economy? Policy and Security measures have been introduced, why does it always seem to be short-lived? Or are the security and policy actions of the Government mere gimmicks to exploit the region of its oil resources? Do the activities of both government and oil majors in the regions contribute to the insecurity?

\section{The Niger Delta Militancy as a Consequence of the Nigerian State Fragility}

Some of the key features of a fragile state as pointed out earlier in the paper include inability to deliver the most basic services and meet vital development needs, inability to maintain a monopoly of the possession and use of instruments of violence and high propensity for persistent violent conflicts or agitations for justice and social needs.It is pertinent to observe that the situation in the Niger Delta region is, indeed, a paradox of poverty and underdevelopment in the mist of plenty. This is because in spite of oil wealth in the region, it still remains one of the least developed parts of Nigeria, apparently characterized by widespread poverty (Ogege, 2011; UNDP, 2006). It is the deep rooted sense of neglect and marginalization by the government in providing or supporting critical human development and provision of basic social amenities that underlay the persistent militancy in the region. Ndoma- Egba (2004) collaborates this argument as he contends that it is the inability of the Nigerian state to address the development needs of the region that has led to the persistent agitation and violent crisis in the region. 
The agitation according to him becomes more violently expressed on the belief that the failure of the Nigerian state to meet their basic development needs is deliberate and a consequence of sheer lack of political will on the part of government leadership. In essence, the militants feel that they are in unjust situation and need to rise up in arms to redress the situation (Smith, 2002). Nigerian government itself clearly acknowledged this as President Shehu Musa Yar'adua noted in the 2009 Independence Day broadcast that the militants took up arms as a way of drawing attention to the plight of the people of the region.

Generally, it is noteworthy that the very core reason for the existence of the state and peoples' obedience to the state is the expectation that the state will provide the basic necessities of life. Consequently, in the environment of the states' inability or unwillingness to provide the basic needs for the citizens, armed groups may start to emerge as a means of getting answers to their agitation for the protection of their vital interests. This tendency is usually, reinforced by the fact that in such a situation of fragility, the state does not maintain a monopoly of possession and use of instruments of violence. For instance, the magnitude of arms surrendered by the Niger Delta militants following the amnesty indicates that the Nigerian state has come to lack the ability to maintain a monopoly of the possession and use of instruments of violence. Indeed, the much that was surrendered is possibly not even all that the militants had in their arsenal. Clearly, the Niger Delta militancy is a consequence of the Nigerian state fragility with particular reference to its unwillingness and inability to provide basic development needs of the people of the region. Indeed, the people of the region have come to consider it reasonable to form armed groups or join militant groups as a means of meeting their justice and social needs. And if the militancy is allowed to persist, it has the potential to further weaken the power of the Nigerian state to perform its 
functions of providing basic services or development. The initial response to the violent activities of the militants by the Nigerian Federal Government was military repression that involved forceful control of the militant activities through the Joint Military Task Force operations. This approach resulted to monumental loss of human lives with both the militants and the Nigerian security forces claiming to have inflicted heavy casualties on one another (Ikejiani, 2007). However, from 2005, it was becoming clear that the military approach to the control of the violent militant activities in the region was not being effective given its increasing intensity (Kalu, 2014). Following this and the implications of the increasing violence on the socioeconomic life of the region and the nation at large, the late President, Alhaji Shehu Musa Yar'adua on 8th September, 2008, set up a committee called the Niger Delta Technical Committee to recommend appropriate measures to control the militancy in the region.

The fundamental recommendation of the committee was amnesty and disarmament of the Niger Delta militants. In line with this recommendation and precisely on 25th June, 2009, late President Shehu Musa Yar'adua granted amnesty to the militants who had directly or indirectly participated in the commission of offences associated with militant activities in the region and who were willing to surrender their weapons and renounce armed struggle within a 60day ultimatum (6 $6^{\text {th }}$ August -4 th October, 2009) (Akeem, 2010). By the end of the amnesty period in October, 2009, 20, 192 militants had surrendered their weapons consisting of 2,760 arms of different classes and calibre to the Presidential Amnesty Committee (Akeem, 2010).

The disarmed militants were moved to designated collection points and camps in six Niger Delta States. Each militant was promised a payment of sixty-five thousand naira $(\mathrm{N} 65,000)$ only monthly, payment of rent and vocational training. The key programme of the amnesty policy is expected to run for five (5) years 
and so would, all things being equal, terminate by 2015 (Otite and Umukoro, 2012). The Amnesty is intended to restore peace in the region, allow for peaceful operation of the oil companies or exploration activities through which the major source of national income is being realized.

However, given that the basic finding in most studies on the Niger Delta militancy is that the fundamental cause of the militancy is the apparent lack of development in its various dimensions in the region, the key objectives of the paper is, therefore, to: (i) Situate and discuss the Niger Delta militancy in the context of the inability of the Nigerian state to provide essential services and development in the region (ii) To analyze the appropriateness and the inadequacies of the amnesty against the background of the cause of the militancy and; (iii) to recommend measures or reforms towards sustainable peace and development in the region. The work essentially relied on secondary sources of data and information gathering for its discussion and conclusion.

\section{Causes of Militants' Activities in the Niger Delta of Nigeria}

The Niger Delta, Nigeria's oil belt, is home to much of the oil and gas reserves and the oil industry. There were 349 drilling sites, 22 flow stations and one terminal in the early 1990s. (World Bank, 1995) and about $10,000 \mathrm{~km}$ of pipelines, 10 gas plants, 3 oil terminals and 1,500 oil producing wells by the mid 1990's (Egborge, 1999). As at 2007 there were over 600 oil fields, 5,284, on and off shore oil wells, 10 export terminals, 275 flow stations, 4 refineries and an LNG project (Lubeck, Watts and Lipschutz, 2007:5). It has been reported that the Niger Delta and its crude oil had a proven reserve of $17.8 \mathrm{~m}$ barrels and natural gas with proven reserve of $2.5 \times 102 \mathrm{M}$ by early 1998 . Crude oil reserves as at 2000 were estimated at over 30 billion barrels Oil, as expected, has not brought prosperity, better living conditions and government attention and development. Rather, it has been 
accompanied by instability, insecurity, conflicts, violence, crime, and social tensions. The Niger Delta is characterized by the absence of infrastructure, social services, non-oil industries and even petroleum products. There is widespread neglect, social and economic underdevelopment. The region is one of the least developed in the nation. It has only $2 \%$ of the Federal roads and less than $30-40 \%$ of settlements have electricity. In some areas, existing primary health care facilities serve as little as $2 \%$ of the population. Educational facilities are inadequate in most communities. There is huge infrastructure underdevelopment. The prices of petroleum products are of the highest in the country. There is endemic poverty (NDES 1997a).

According to Ikelegbe (2004:490-516) rather than attract development, oil has actually devastated and underdeveloped the region. Oil exploration and exploitation has led to family, intracommunal, inter-communal and inter-ethnic feuds, conflicts and wars. The oil economy has disinherited and dislocated the local people who are dependent on the primary economies of farming, fishing, and hunting. The region has been laid prostrate by massive oil based environmental degradation. As a regime of massive oil spillages and gas flares, their activities have destroyed or devastated enormous land and water which has led to soil fertility loss, agricultural decline, forest loss, fisheries decline and biodiversity depletion (Ikelegbe, 2008).

The region which only receives little resources as derivation based resource flow from the federation account had its resources decline from $50 \%$ in 1966 , to $45 \%$ in $1970,1 \%$ in $1979,2 \%$ in $1982,1.5 \%$ in 1984 and $3 \%$ in 1992. It was only increased to $13 \%$ in 1992. As Ikelegbe (2004: 490-916) has noted, the import of trickle resources flows from the Nigerian state and the oil companies and the consequences of gross degradation and socio-economic dislocation has been massive poverty, unemployment and malnutrition among the 
people. These have led to frustration, restiveness, anger, bitterness and aggression against the state and the oil companies through various means by militants' groups.

\section{Development and Socio-Cultural Implications of the Crisis}

The crisis has had major implications for development and sociocultural relations in the Niger Delta in particular and in Nigeria as a whole. As a general principle, it is a fact that development and crisis cannot go hand in hand. This means that the generalized crisis in the Niger Delta has severe negative implications for the development of the area and Nigeria as a whole. More specifically observable are the following development and socio-cultural consequences.

1. The crisis has cracked relations within and between communities and various social groups in the Niger Delta. The crisis has broken relations between the communities in the Niger Delta and the Nigerian state.

2. The crisis has fractured relations between the communities in the Niger Delta and the oil companies.

3. The crisis has affected jobs and job creation in the Niger Delta as oil companies withdraw from areas of operation and shut down production activities and new businesses consider the area one of high risk.

4. The crisis has affected the security of oil workers, members of their families and areas of work activities.

5. The crisis has resulted in huge revenue losses for the country (shut down of production activities, vandalization and damage of oil facilities, bunkering, etc.).

6. The crisis has been used to sponsor other types of crisis, especially at the political level where as the Truth and Reconciliation Commission in Rivers State has shown, politicians 
hide under the general crisis in the Niger Delta to settle personal scores.

7. The crisis has also affected the image of the people of the area; (they are seen as crisis and conflict prone).

8. The crisis has contributed to global increase in fuel prices.

\section{Containment of the Crisis}

Given the major negative implications of the crisis for all interests involved, it is not surprising to find that a number of initiatives have been adopted by the Nigerian state and the oil companies to assuage the 'anger' of the communities in the Niger Delta. Among the initiatives, the following have been popular:

1. The projects approach (undertaking such projects as building hospitals, schools, etc.)

2. The agency approach (establishing development agencies such as NDE, OMPADEC and NDDC)

3. The political empowerment approach (creation of local governments, States and geopolitical zones; appointment of prominent individuals from the Niger Delta to positions of national leadership)

4. Providing development frameworks (establishing Plans for development such as Master Plans, National / State Economic Empowerment Development Strategies - NEEDS, SEEDS, LEEDS, or enunciating national policies as in the National Policy on Poverty Eradication which are then passed on to other state institutions and agencies to implement)

5. The financial empowerment approach (giving cash or block grants to states and communities, providing micro credits to community members through third parties, etc.)

6. The rule making approach (as in the Revenue Derivation Formula, making laws and regulations for the 'development' of the Niger 
Delta or as part of some general legislation on property rights, environmental, etc.)

7. The talk-shop approach (convening National Summits on the Niger Delta; inviting leaders recognized by the state and the oil companies for discussions / consultations, etc.).

\section{Amnesty Policy of Nigerian Government on Niger Delta Militancy}

As the Nigerian Government unleashed its state terror through its violent repression, the social movement which has become violent at this stage became more violent in its approach as the number of militant groups increased, making it very difficult to explore and exploit oil in the region. Consequently, the 2.5 million barrels of oil production per day in Nigeria dropped to less than half of that number, making Angola which was the second highest oil producing country in Africa to become the first.

Faced with the reality of such a drastic drop in oil production and its implications on the country whose economy is heavily dependent on oil, President Yar'Adua took a non-violent path in resolving the crisis in the region in its bid to patch the bleeding economy. Thus, on 24th June, 2009 he announced the 60-day amnesty policy.

The policy which lacked much detail only stated that militants who lay down their arms within 60 days (6th August 2009-4th October 2009) will not be prosecuted for the crimes committed in the process of crippling Nigeria's oil industry. Since the announcement of the amnesty policy, thousands of ammunitions, machine guns and grenade launchers have been handed in. Many militants have turned themselves in as well though major militant groups like the Movement for the Emancipation of the Niger Delta (MEND) which viewed the policy with suspicion promised cease fire but not disarmament of the group because according to them, the policy has no room for dialogue and it does not address the root issues that gave 
birth to the struggle. However, the policy seems to be a success because its announcement and the seeming compliance of the militants brought relative peace to the long troubled region for the first time.

Unfortunately, these initiatives have not and cannot work because they share individually and collectively some common weaknesses. The first and most fundamental weakness is that they are based upon a wrong understanding of the essence of the crisis and hence challenge of development in the Niger Delta. A second weakness which they all share is that the adopted solutions are at best not sincere and at worst, constructed to maintain the status quo. This explains the deliberate subversion of the development programmes by the very state officials who approve them. Thirdly, they are usually commandist in nature. They are the ideas of those who are responsible for the crisis in the Niger Delta, rather than those of the people of the Niger Delta.

\section{Frustration Aggression Theory}

This theory explains why people become frustrated and aggressive when their goals and aspiration are not achieved. In 1939, researchers at Yale University Institute of Human Relation published a small monograph that has had a tremendous impact directly or indirectly, almost on all behavioral sciences. Led by John Dollard, Leonard Doob, Neal Miller, O.H. Mower, and Robert Sear (1939), the group attempted to account for virtually all human aggression with a few basic ideas. Most of the studies investigating the causes and consequences of aggression in the immediately following decades were oriented, to some extent, at least towards issues raised by the Yale's group analysis. Frustration can create aggressive inclination even when they are not arbitrary or aimed at the subject personally. According to Maslow (1941), the usual definitions of frustration are in terms simply of not getting what one desires, of interference with a 
wish, or with a gratification. Such a definition fails to make the distinction between a deprivation which is unimportant to the organism (easily substituted for, with few serious after-effects), and, on the other hand, a deprivation which is at the same time, a threat to the personality, that is, to the life goals of the individual, to his defensive system, to his self-esteem or to his feeling of security. It is our con-tension that only a threatening deprivation has the multitude of effects (usually undesirable) which are commonly attributed to frustration in general. Militants activities in Nigeria's Niger Delta therefore is mostly motivated by frustration created by deprivation and a threat to the personality, that is, to the life goals of individual or a group of people in the region.

The region derives its name from being situated at the mouth of the River Niger. Before the creation of the Nigerian state, economic activities of the Niger Delta in pre-colonial days entailed mainly export of salt and fish to the hinterland. In the 18th century, when the slave trade was at its peak, the region was West Africa's largest slave exporting area, and this was enhanced by its proximity to the sea. Slave traders, however, diverted to palm oil trade in the 19th century when the slave trade declined. The Niger Delta, the delta of the Niger River in Nigeria, is a densely populated region sometimes called the Oil Rivers because it was once a major producer of palm oil. The area was the British Oil Rivers Protectorate from 1885 until 1893, when it was expanded and became the Niger Coast Protectorate.

The Niger Delta, as now defined officially by the Nigerian government, extends over about $70,000 \mathrm{~km}^{2}$ and makes up $7.5 \%$ of Nigeria's land mass. Historically and cartographically, it consists of present day Bayelsa, Delta, and Rivers States. In 2000, however, Obansanjo's regime included Abia, Akwa-Ibom, Cross River State, Edo, Imo and Ondo States in the region. Some 31 million people of more than 40 ethnic groups including the Bini, Efik, Ibibio, Annang, 
Oron, Ijaw, Itsekiri, Isoko, Urhobo, Ukwuani, and Kalabari, are among the inhabitants in the Niger Delta, speaking about 250 different dialects.

As Nigeria began to prepare for independence, the search for oil began in the Delta in the 1950s and by 1956 it was discovered in commercial quantities. Less than two years later it was being commercially produced and sold on the international markets. Today around two million barrels of oil are extracted in the Niger Delta every day making it the world's eighth largest oil producer in a country that remains one of the world's poorest as the oil revenues largely bypass those living and working outside that industry.

Foreign companies extract the oil and it has been alleged that they do so without regard for local cultures or the local environment which has been ravaged by oil spills, fires, pollution, deforestation and poor waste management.

\section{Conclusion}

The Niger Delta Militancy is a consequence of the failure of the Nigerian state to deliver basic services and development in the region. An effective and sustainable control of the militancy in the region requires, therefore, an accelerated and holistic development of the region to compliment the successes of the amnesty policy. Achieving this development basically requires a positive attitudinal change on the part of the state and national political leaderships in the direction of using effectively the available resources for socio-economic development. Such is not only necessary for the control of the existing Niger Delta Militancy but for forestalling future ones that may be induced by similar neglect of development needs of people in the other parts or regions of Nigeria. 


\section{Recommendations}

Basically, effective control of the militancy and the realization of sustainable peace and stability in the region require a rapid and integrated development of the region through the provision of social and physical infrastructural facilities, ecological/environmental remediation and creation of opportunities for human capital development. Government need to realize that development is not an event but a process and so it has to create a holistic framework or strategy to ensure sustainable and adequate provision of the development needs of the people of the region. Beyond government's direct efforts in the development process of the region, government has again to put in place mechanisms or strategies to ensure that the oil companies in the region abide strictly by the environmental standards for air, land and water pollution. There is equally the need for strategies to ensure that oil companies increase their overall contribution towards human and infrastructural development in the region.

The following recommendations are also required towards resolving the Niger Delta crises.

1. Nigerian government should return to derivative /resource control measure at resolving the crises in Niger Delta. The issue of resource control should be entrenched in the concurrent list to avoid over centralization in resource allocation. It should be wellestablished so that communities can negotiate for royalties on the resources located on their land with exploring companies.

2. The federal government should reorganize the state apparatus to reflect true federalism for component units.

3. Special attention should be paid to the investment in the development of people and delta region.The Niger Delta ministry and NDDC should not be politicized but encouraged to accomplish the goals for which they are established. 
4. Severe measures should be taken against oil companies that do not stick to pollution free environment, carry out set corporate social responsibilities to their host communities or recompense adequately the host communities for oil spillage and properties acquired.

5. Regular discourse among the stake holders is suggested to avoid cumulated aggression. The obligation is on all levels of government and oil prospecting companies to aid such dialogue and execute all agreements reached.

The extent to which the above recommended development can be realized, however, is dependent on the determination and resolve of both the national government as well as the government leadership of the states and local government within the region to institutionalize good governance which is a veritable framework for effective and efficient development administration. So the basic challenge for both the national, state and local government leadership should be on how to strengthen accountability in government institutions like the OMPADEIC, NDDC and the Ministry of the Niger Delta to facilitate effective service delivery and development in the region.

For the people of the region, their agitation should also focus on compelling the political leaders in the region to always prudently use available fund for development of the region. This could principally be done through initiating and engaging in political activities to engender greater accountability and more effective representation by their political leaders.

Voke Charles Mgbonyenbi Political Science Department College of Education, Agbor \&

Frank C.A. Emeni

Department of History

College of Education, Agbor 


\section{References}

Achebe, C. (1983) The Trouble with Nigeria. Enugu: Fourth Dimension Publishers

Akeem, A. (2010) "Amnesty and Human Capital Development: Agenda for the Niger Delta". Journal of African Studies and Development. Vol. 2(8) Pp $201-207$.

Aziki, S. (2007) Oil Gas and Life in Nigeria. Ibadan: Y-books Ltd.

Derin, K. (2007) "Leadership, Government and Corruption in Nigeria" Journal of Sustainable Development in Africa pp 915.

Dike, V. (2003) Nigeria and politics of Unreason: A study of the Politic Obasanjo Regime, London: Adonis and Abbey Publishers Ltd.

Enu, D. and Ugwu, U. (2011) "Human Security and Sustainable Peace Building in Nigeria: The Niger Delta Perspective". Journal of Sustainable Development. Vol. 4 No. 1. Pp 66-72.

Ezeudo, A. (2013) "State Fragility and Violence: A Case Study of Failing Amnesty Programme in Niger Delta States of Nigeria". An Unpublished Thesis, Institute of Management and Technology, Enugu.

Grazialla, B. and Andrea, G. (2013) "Growth, History or Institutions? What Explains State Fragility in Sub-Sahara Africa" IZA Discussion Paper, No 4817, Bonn, Germany.

Hangman, T. and Hoechne, M. (2009) "Failures of the State Failure Debate: Evidence from the Somalia Territories" Journal of International Development. Vol. 1 Pp 42 - 57.

Human Rights Watch (2002) The Niger Delta: No Democracy Dividend New York: Human Rights Watch.

Ibaba, S. (2005) Understanding the Niger Delta Crisis. Port Harcourt Amethyst and Colleagues.

Ikein, A. (2009) "The Potential Power of West African Oil to the Economics and Energy security Interest of Euro-America in 
the 21st Century". Journal of Sustainable Development in Africa Vol. 10(3) Pp 540 - 556.

Ikejiani, M. (2007) "Nigeria Oil: Internal Threats and Vulnerability" Journal of International Politics and Development Studies Vol. 3 No 1 July/Dec. pp 6-10.

IMF (2003) Oil Revenue and Budgeting in Nigeria. Official Bulletin No. 6.

Kalu, O. (2014) "Fighting Insecurity the Old Way" The Sun, Feb. 1st. Kuku (2014) "Federal Government to End Niger Delta Amnesty by 2015" Africa Pilot. Feb. 14.

Lain, A. (2010) "Rebels in Court over Nigerian bombings" The Telegraph, October, 3.

Ndoma-Egba, V. (2004) "Forced Unity: The Nationality Question". In O.E. Uya (ed) Civil Society and the Consolidation of Democracy in Nigeria. Being Proceeding of IPPA International Seminar held at Chinua Achebe New Arts Theatre, University of Calabar, From 25 - 26th May, 2000.

OECD (2007) "Principles for Good International Engagement in Fragile States: Learning and Advisory Process on Different development Assistance Committee" (DAC). Organization for Economic Development, Paris.

OECD (2013) "Fragile States: Resource Flows and Trends in a Shifting World" DAC International Network on Conflict and Fragility, UK.

Ogege, S. (2011) "Amnesty Initiative and the Dilemma of Sustainable Development in the Niger Delta Region of Nigeria" Journal of Sustainable Development. Vol 4 No 4. Pp 101-108.

Review of Public Administration and Management Vol. 3, No. 6, December 201486

Ojieh, C. (2010) "The Niger Delta Crises: A Focus on post Amnesty, Militancy and National Security" African Journal of International Affairs. Vol. 3 No. 1and2 pp. 1-14. 
Ojo, O. (2007) The Niger Delta: Managing Resources and conflict. Ibadan: Development Policy Centre.

Olatoke, J. and Olotokunba, S. (2012) "An Examination of the Constitutionality of the Amnesty Programme in the Niger Delta Region of the Federal Republic of Nigeria". Journal of Law, Policy and Globalization. Vol.(5) pp 115-120.

Onduku, A. (2011) Environmental Conflicts: The Case of the Niger Delta. Warri: Urhobo Historical Society.

Otite, A. and Umuokoro, N. (2011) "Amnesty Programme and the Niger Delta: Overview of Disarmament, Demobilization and Re-integration Strategy for Sustainable Peace in Nigeria". Special Issues Vol. 5 No. 1 Pp 215 - 237.

Rothberg, R. (2004) "The Failure and Collapse of Nation States" In When States Fail: Causes and Consequences. Prince Town: University Press.

Smith, O. (2002) Trends and Causes of Armed Conflict. Berghof: Research Cenre for Constructive Conflict Management.

Steward, F. and Brown, G. (2010) "Fragile States: CRISE Overview" CRISE, Oxford.

Tell Magazine (2008) "50 Ye ars of Oil in Nigeria". February, 18.

Tell Magazine (2011) "Trial of Ex-governors: Another Offensive to No where" October, 29.

Tom, B. and Torsten, P. (2011) "Institutions, Violence and Growth in Fragile States" IGC Oxford Workshop in Fragile States.

Udeaghan, E. (2008) "How Oil Firms Investors can Secure their Investment in the Niger Delta". Vanguard Newspaper, June, 6.

UNDP (2006) Niger Delta Human Development Report. Lagos: Perfect Printers.

World Bank (2005) Fragile States - Good Practice on Country Assistance Strategy Washington DC: World Bank. 